\title{
Meteorological Data for Water Years 1988-94 from Five Weather Stations at Yucca Mountain, Nevada
}

by Alan L. Flint and William J. Davies

$$
\text { USGS-OFR--96-462 }
$$

\section{U.S. GEOLOGICAL SURVEY}

Open-File Report 96-462

Prepared in cooperation with the

NEVADA OPERATIONS OFFICE,

U.S. DEPARTMENT OF ENERGY, under

Interagency Agreement DE-Al08-92NV10874

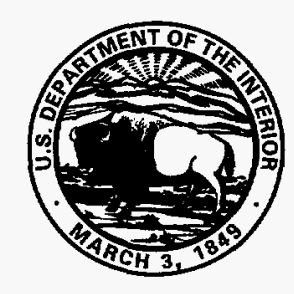




\title{
U.S. DEPARTMENT OF THE INTERIOR \\ BRUCE BABBITT, Secretary
}

\author{
U.S. GEOLOGICAL SURVEY
}

Gordon P. Eaton, Director

The use of firm, trade, and brand names in this report is for identification purposes only and does not constitute endorsement by the U.S. Geological Survey.

For additional information write to:

Chief, Earth Science Investigations Program Yucca Mountain Project Branch

U.S. Geological Survey

Box 25046, Mail Stop 421

Denver Federal Center

Denver, CO 80225-0046
Copies of this report can be purchased from:

U.S. Geological Survey

Branch of Information Services

Box 25286

Denver, CO 80225-0286 


\section{DISCLamiar}

Portions of this document may be illegible in electronic image products. Images are produced from the best available original docment. 


\section{DISCLAIMER}

This report was prepared as an account of work sponsored by an agency of the United States Government. Neither the United States Government nor any agency thereof, nor any of their employees, makes any warranty, express or implied, or assumes any legal liability or responsibility for the accuracy, completeness, or usefulness of any information, apparatus, product, or process disclosed, or represents that its use would not infringe privately owned rights. Reference herein to any specific commercial product, process, or service by trade name, trademark, manufacturer, or otherwise does not necessarily constitute or imply its endorsement, recommendation, or favoring by the United States Government or any agency thereof. The views and opinions of authors expressed herein do not necessarily state or reflect those of the United States Government or any agency thereof. 


\section{CONTENTS}

Abstract.

Introduction

Study Area Description .

Instrumentation

Meteorological Data

Summary.

References Cited.

\section{FIGURE}

1. Map showing locations of eight weather station sites at Yucca Mountain, Nevada

\section{TABLES}

1. Location, elevation, and date of coverage for each weather station

2. Instrumentation used for each weather station

3. Daily meteorological data from weather station WX-3 for June 21, 1994

4. Maximum and minimum monthly air temperature for five weather stations for water year 1992

5. Total monthly precipitation for five weather stations for water year 1992

6. Maximum and minimum monthly air temperature for weather station WX-3 for water years $1988-94$

7. Total monthly precipitation values for weather station WX-3 for water years $1988-94$

\section{CONVERSION FACTORS}

\begin{tabular}{rll}
\hline Multiply & \multicolumn{1}{c}{ By } & To obtaln \\
\hline millimeter $(\mathrm{mm})$ & 0.03937 & inch \\
meter $(\mathrm{m})$ & 3.28 & foot \\
watt $(\mathrm{w})$ & 3.412 & BTU per hour \\
joule & $9.48 \times 10^{-4}$ & BTU, British thermal unit \\
kilometer $\left(\mathrm{km}^{2}\right)$ & 0.6214 & mile $(\mathrm{mi})$ \\
square kilometer $\left(\mathrm{km}^{2}\right)$ & 0.3861 & square mile $\left(\mathrm{mi}^{2}\right)$ \\
watts $\left(\mathrm{w} / \mathrm{m}^{2}\right)$ per square $\mathrm{meter}$ & 0.319 & BTU per square foot per hour \\
megaJoules per square meter $\left(\mathrm{MJ} / \mathrm{m}^{2}\right)$ & 1141.77 & BTU per square foot \\
kilopascal $(\mathrm{kPa})$ & 0.145 & pound-force per square inch
\end{tabular}

Temperature in degrees Celsius $\left({ }^{\circ} \mathrm{C}\right)$ may be converted to degrees Fahrenheit $\left({ }^{\circ} \mathrm{F}\right)$ as follows:

$$
{ }^{\circ} \mathrm{F}=\left(1.8 \times{ }^{\circ} \mathrm{C}\right)+32
$$





\title{
Meteorological Data for Water Years 1988-94 from Five Weather Stations at Yucca Mountain, Nevada
}

\author{
By Alan L. Flint and William J. Davies
}

\section{Abstract}

This report describes meteorological data collected from five weather stations at Yucca Mountain, Nevada, from as early as April 1987 through September 1994. The measurements include solar radiation, temperature, relative humidity, wind speed, wind vector magnitude, wind direction, wind vector direction, barometric pressure, and precipitation. Measurements were made every 10 seconds and averaged every 15 minutes. The data were collected as part of the geologic and hydrologic site-characterization studies of Yucca Mountain, a potential repository for high-level radioactive waste.

Precipitation at the site ranged from a low of 12 millimeters total for water year 1989 to a high of 312 millimeters total for water year 1993. Air temperature ranged from a low of 15.1 degrees Celsius in December 1990 (water year 1991) to a high of 41.9 degrees Celsius in July 1989 (water year 1989). The weather station network also provides information on the spatial variability of precipitation and temperature.

\section{INTRODUCTION}

Yucca Mountain, Nevada, is being evaluated as a potential site for the storage of high-level radioactive waste in a geologic repository (U.S. Department of Energy, 1988). As part of this study, the U.S. Geological Survey (USGS) is collecting meteorological data. Meteorological data are needed to help characterize present net infiltration rates and to develop models for predicting changes in infiltration rates in response to potential changes in climate and surface characteristics. The data from this study are intended to support studies of precipitation, infiltration, and evapotranspiration to help characterize the surfacewater budget for Yucca Mountain. The purpose of this report is to describe the data collected since 1987, for water year 1988. A water year is the continuous 12-month period that begins October 1 and ends September 30, designated by the calendar year in which it ends.

\section{Study Area Description}

Yucca Mountain, Nevada, is a north-southtrending block-faulted ridge located within the southern part of the Basin and Range physiographic province and within the northern part of the Mojave Desert. It is located in the rain shadow of the Sierra Nevada and is considered one of the driest locations in the United States. The Mojave Desert is classified as a warm desert, receiving most of its precipitation as rain. There are two distinctly different storm patterns affecting the desert climate in this area, one in winter, the other in summer. Winter precipitation tends to be of low intensity and long duration (days) and covers large areas. In contrast, most summer rains result from convective thunderstorms of high intensity and short duration (hours) that cover less than $2-3 \mathrm{~km}^{2}$. Less than $48 \mathrm{~km}$ to the north is the southern boundary of the Great Basin Desert, a cold desert. Conditions may arise that allow winter storms to move south from the Great Basin Desert toward the study area, bringing snow and cold temperatures in the winter. Because the study area is near the boundary of two distinctly different desert systems, meteorological conditions may vary considerably. The area of interest in this study is the potential repository and surrounding area encompassed by the weather stations shown in figure 1 . 
UNIVERSAL TRANSVERSE MERCATOR EASTING, IN METERS

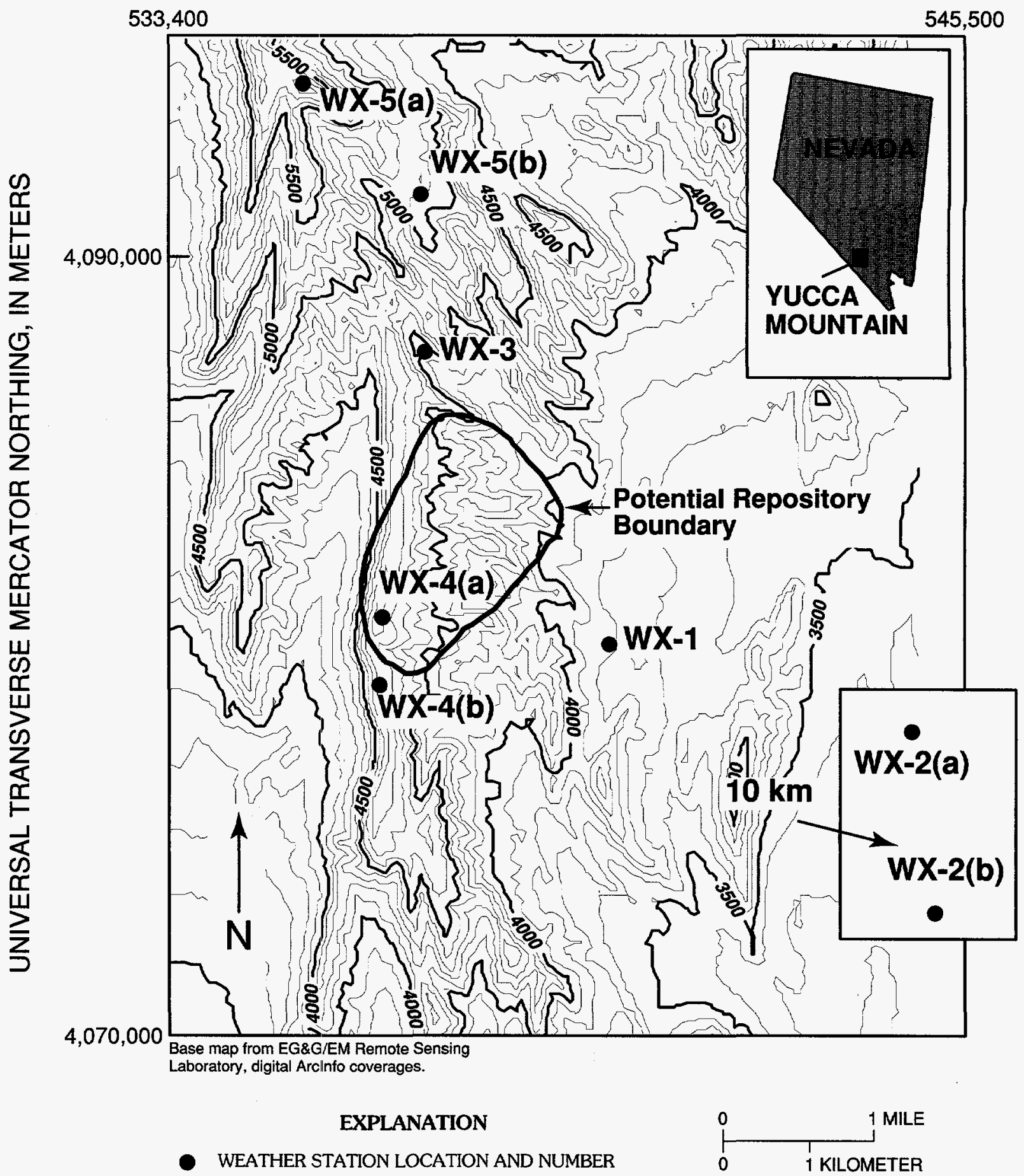

Figure 1. Locations of eight weather station sites at Yucca Mountain, Nevada. 


\section{Instrumentation}

Two weather stations were installed in early 1983 and 1984 to monitor environmental conditions during drilling activities. In 1987, these two weather stations were rebuilt at the same location with new instruments, and two additional weather stations were added to the network (table 1). In 1988, a final weather station was added. The weather station instrumentation was chosen for two purposes: (1) To provide local information on solar radiation, temperature, relative humidity, wind speed, wind direction, barometric pressure, and precipitation; and (2) to provide the minimal information necessary to make estimates of potential and actual evapotranspiration using the Penman equation or the Priestley-Taylor equation (Monteith and Unsworth, 1990; Flint and Childs, 1991).

All instruments for each weather station were attached to a tripod except for the tipping-bucket rain gage. The rain gage was located on the ground away from, but within $5 \mathrm{~m}$ of the station to minimize wind effects around the weather station. A data logger was used to sample the sensors every 10 seconds and to average the measurements every 15 minutes. The tipping-bucket rain gage was event-driven with the counter checked every 10 seconds. If tips occurred, then the time of the tip was recorded (to within 10 seconds). During high-intensity precipitation events, multiple tips could be recorded. The manufacture, model, and accuracy for each instrument is given in table 2 (barometric pressure was recorded only at weather station WX-3). In addition to the 15-minute data, a daily record was generated. The daily record consists of total solar radiation data, minimum and maximum air temperature and relative-humidity data, and the time of collection of minimum and maximum air temperature and relative-humidity data. These data were derived from the data collected every 10 seconds. Although the weather station numbers remained the same, they were sometimes relocated from one site to another during the study.

\section{METEOROLOGICAL DATA}

The data are presented in four types of files and are available as ASCII files from the USGS (Denver) repository site on the Internet. These data are available online (via anonymous ftp) at ympbsrv1.cr.usgs.gov or from the Chief, Earth Science Investigations Program. A daily file consists of the ninety-six 15-minute records of time (Pacific standard time), temperature $\left({ }^{\circ} \mathrm{C}\right)$, relative humidity (percent), solar radiation $\left(\mathrm{w} / \mathrm{m}^{2}\right)$, wind speed $(\mathrm{m} / \mathrm{s})$, wind vector magnitude $(\mathrm{m} / \mathrm{s})$, wind direction (azimuthal degrees) or wind vector (azimuthal degrees), and barometric pressure $(\mathrm{kPa})$. The daily files are designated as WX\#_DOY.OYR, where WX\# is the weather station number, DOY is the three-digit day of year (001-366), and YR is the last two digits of the calendar year.

Prior to mid-January 1990, the wind direction was recorded as the average of ninety 10 -second readings. After mid-January, wind vector direction was calculated instead. The wind vector direction is the wind direction linearly weighted by the wind speed. The higher the wind speed over a 10 -second reading, the more weight given to the wind direction. When the wind speed is zero, the wind direction is not counted. The wind vector magnitude is the average magnitude of the wind speed for that wind vector direction. To keep the data files as consistent as possible, a column was created for wind vector magnitude for all daily data files. A -99 appears in that column if the data were not yet collected. (Note: -99 is used to denote missing or bad data in all cases). When the weather station program was changed to collect wind vector magnitude and wind vector direction, the data in the wind direction column changes to wind vector direction. An example of a daily-data file is presented in table 3.

The temperature and relative-humidity sensor was placed in an R.M. Young self-aspirated radiation shield at $2 \mathrm{~m}$ above land surface. The relativehumidity data tended to drift over the 1-year field life; at low humidities ( $<50$ percent), the measured relative humidity was insensitive to small changes in humidity. When the calibration data differed between pre-installation and post-installation, a linear drift was assumed and the data were corrected. Data were not adjusted for insensitivity. Insensitivity to small changes can be seen in the daily data files as slowly changing relative humidity at low humidities. The overall trend of humidity appears to be correct when compared with the other weather stations.

Barometric pressure was collected only at weather station WX-3. The horizontal variability barometric pressure probably is small over the study area, but the effects of differences in elevation should be accounted for. For 2 weeks (days 241-254, 1987), 
Table 1. Location, elevation, and date of coverage for each weather station

[Weather stations WX-1, WX-2, WX-4, and WX-5 were moved during the time of data collection and are indicated by (a) for first location and (b) for second location; Northing and Easting are in Universal Transverse Mercator (NAD 27) coordinates]

\begin{tabular}{crcccc}
\hline & \multicolumn{5}{c}{ Locations } \\
\hline $\begin{array}{c}\text { Weather } \\
\text { station ID }\end{array}$ & $\begin{array}{c}\text { Northing } \\
\text { (meters) }\end{array}$ & $\begin{array}{c}\text { Easting } \\
\text { (meters) }\end{array}$ & $\begin{array}{c}\text { Elevation } \\
\text { (meters) }\end{array}$ & $\begin{array}{c}\text { Beginning } \\
\text { date }\end{array}$ & Ending date \\
\hline WX-1 & $4,076,521$ & 550,424 & 1,163 & $01 / 01 / 88$ & $09 / 30 / 94$ \\
WX-2(a) & $4,075,931$ & 564,332 & 1,154 & $04 / 18 / 87$ & $03 / 07 / 89$ \\
WX-2(b) & $4,071,986$ & 563,430 & 1,055 & $03 / 07 / 89$ & $09 / 30 / 94$ \\
WX-3 & $4,080,316$ & 548,038 & 1,351 & $07 / 16 / 87$ & $09 / 30 / 94$ \\
WX-4(a) & $4,076,856$ & 547,504 & 1,498 & $07 / 01 / 87$ & $06 / 08 / 90$ \\
WX-4(b) & $4,075,990$ & 547,481 & 1,489 & $06 / 08 / 90$ & $09 / 30 / 94$ \\
WX-5(a) & $4,083,775$ & 546,453 & 1,789 & $06 / 23 / 88$ & $10 / 04 / 93$ \\
WX-5(b) & $4,082,370$ & 547,984 & 1,563 & $10 / 04 / 93$ & $09 / 30 / 94$ \\
\hline
\end{tabular}

${ }^{1}$ Nevada State Coordinates are used to identify location of weather stations cited in this report. These coordinates are for the central zone of Nevada and are based on a Transverse Mercator projection. The origin of this projection for the central zone of Nevada is latitude $34^{\circ} 45^{\prime} \mathrm{N}$., and the central meridian is at longitude $116^{\circ} 40^{\prime} \mathrm{W}$. The coordinates listed in this report are in meters north of the baseline and in meters east of the central meridian.

Table 2. Instrumentation used for each weather station

[ ${ }^{\circ} \mathrm{C}$, Celsius; $\mathrm{m} / \mathrm{s}$, meters per second; $\mathrm{kPa}$, kilopascals; $\mathrm{N} / \mathrm{A}$, not applicable]

\begin{tabular}{llrc}
\hline \multicolumn{1}{c}{ Instrument } & \multicolumn{1}{c}{ Manufacturer } & Model & $\begin{array}{c}\text { Manufacturers' stated } \\
\text { accuracy }^{1}\end{array}$ \\
\hline Pyranometer & Li-Cor & LI-200SZ & 5 percent \\
Temperature & Campbell Scientific & 207 & $0.4^{\circ} \mathrm{C}$ \\
Relative humidity & Campbell Scientific & 207 & 5 percent \\
Wind speed & Met-One & $024 \mathrm{~A}$ & $0.11 \mathrm{~m} / \mathrm{s}$ \\
Wind direction & Met-One & $014 \mathrm{~A}$ & 5 degrees \\
Rain gage & Sierra Misco & 2501 & 2 percent \\
Barometric pressure & Setra & 270 & $0.02 \mathrm{kPa}$ \\
Data logger & Campbell Scientific & $21 \mathrm{X}$ & $\mathrm{N} / \mathrm{A}$ \\
\hline
\end{tabular}

Data logger

${ }^{1}$ The actual accuracies may vary depending on each individual instrument calibration. The values reported here are for reference only. Actual instrument calibration data can be requested from the Chief, Earth Science Investigations Program, U.S. Geological Survey, Box 25046, MS-421, Denver, CO 80225). 
Table 3. Daily meteorological data from weather station WX-3 for June 21,1994

[Time of day in Pacific standard time; ${ }^{\circ} \mathrm{C}$, degrees Celsius; w/m² , watts per square meter; $\mathrm{m} / \mathrm{s}$, meters per second; deg, degrees; $\mathrm{kPa}, \mathrm{kilopascals]}$

\begin{tabular}{|c|c|c|c|c|c|c|c|}
\hline $\begin{array}{c}\text { Time of } \\
\text { day }\end{array}$ & $\begin{array}{c}\text { Air temperature } \\
\left({ }^{\circ} \mathrm{C}\right)\end{array}$ & $\begin{array}{l}\text { Relative } \\
\text { humidity } \\
\text { (percent) }\end{array}$ & $\begin{array}{c}\text { Solar } \\
\text { radiation } \\
\left(\mathrm{w} / \mathrm{m}^{2}\right)\end{array}$ & $\begin{array}{l}\text { Mean wind } \\
\text { speed } \\
(\mathrm{m} / \mathrm{s})\end{array}$ & $\begin{array}{l}\text { Mean wind vector } \\
\text { magnltude } \\
\text { (m/s) }\end{array}$ & $\begin{array}{l}\text { Wind vector } \\
\text { direction } \\
\text { (azimuthal deg) }\end{array}$ & $\begin{array}{c}\text { Barometrlc } \\
\text { pressure } \\
\text { (kPa) }\end{array}$ \\
\hline 0015 & 21.0 & 27 & 0 & 2.2 & 2.1 & 319 & 86.654 \\
\hline 0030 & 20.9 & 28 & 0 & 2.1 & 2.0 & 311 & 86.647 \\
\hline 0045 & 21.0 & 29 & 0 & 1.7 & 1.4 & 302 & 86.650 \\
\hline 0100 & 20.6 & 29 & 0 & 1.9 & 1.8 & 313 & 86.652 \\
\hline 0115 & 20.6 & 29 & 0 & 1.8 & 1.7 & 309 & 86.657 \\
\hline 0130 & 20.5 & 30 & 0 & 2.0 & 2.0 & 305 & 86.654 \\
\hline 0145 & 20.6 & 30 & 0 & 1.8 & 1.8 & 308 & 86.650 \\
\hline 0200 & 20.7 & 30 & 0 & 1.7 & 1.3 & 330 & 86.651 \\
\hline 0215 & 20.5 & 31 & 0 & 1.7 & 1.5 & 313 & 86.650 \\
\hline 0230 & 20.2 & 32 & 0 & 1.9 & 1.8 & 309 & 86.650 \\
\hline 0245 & 19.8 & 33 & 0 & 1.9 & 1.8 & 321 & 86.650 \\
\hline 0300 & 20.1 & 33 & 0 & 2.0 & 1.9 & 318 & 86.645 \\
\hline 0315 & 20.1 & 33 & 0 & 1.6 & 1.5 & 305 & 86.653 \\
\hline 0330 & 20.3 & 33 & 0 & 1.8 & 1.7 & 307 & 86.653 \\
\hline 0345 & 20.1 & 34 & 0 & 1.7 & 1.7 & 313 & 86.659 \\
\hline 0400 & 19.7 & 35 & 0 & 2.1 & 2.1 & 314 & 86.663 \\
\hline 0415 & 19.4 & 36 & 0 & 2.1 & 2.0 & 317 & 86.667 \\
\hline 0430 & 19.2 & 37 & 1 & 2.1 & 2.0 & 321 & 86.676 \\
\hline 0445 & 19.0 & 38 & 4 & 2.1 & 2.0 & 306 & 86.680 \\
\hline 0500 & 19.0 & 39 & 8 & 2.2 & 2.2 & 321 & 86.685 \\
\hline 0515 & 19.1 & 39 & 16 & 1.9 & 1.8 & 317 & 86.692 \\
\hline 0530 & 19.5 & 39 & 34 & 1.8 & 1.8 & 308 & 86.702 \\
\hline 0545 & 20.2 & 38 & 61 & 1.4 & 1.3 & 296 & 86.700 \\
\hline 0600 & 21.4 & 37 & 83 & 1.1 & 1.0 & 337 & 86.705 \\
\hline 0615 & 22.3 & 36 & 73 & 0.7 & 0.3 & 339 & 86.721 \\
\hline 0630 & 23.0 & 35 & 64 & 1.5 & 1.5 & 114 & 86.731 \\
\hline 0645 & 23.5 & 35 & 236 & 1.3 & 1.3 & 115 & 86.733 \\
\hline 0700 & 25.5 & 33 & 396 & 2.3 & 2.2 & 133 & 86.735 \\
\hline 0715 & 26.3 & 32 & 448 & 2.5 & 2.4 & 126 & 86.751 \\
\hline 0730 & 26.8 & 31 & 504 & 2.0 & 1.9 & 125 & 86.759 \\
\hline 0745 & 27.6 & 29 & 570 & 1.9 & 1.6 & 138 & 86.755 \\
\hline 0800 & 28.1 & 29 & 554 & 2.2 & 2.0 & 140 & 86.752 \\
\hline 0815 & 28.1 & 28 & 615 & 2.6 & 2.4 & 136 & 86.753 \\
\hline 0830 & 28.2 & 27 & 595 & 2.4 & 2.2 & 114 & 86.755 \\
\hline 0845 & 28.4 & 26 & 775 & 2.5 & 2.2 & 112 & 86.751 \\
\hline 0900 & 28.6 & 26 & 817 & 3.9 & 3.6 & 139 & 86.749 \\
\hline
\end{tabular}


Table 3. Daily meteorological data from weather station $W X-3$ for June 21,1994 Continued

[Time of day in Pacific standard time; ${ }^{\circ} \mathrm{C}$, degrees Celsius; w/m², watts per square meter; $\mathrm{m} / \mathrm{s}$, meters per second; deg, degrees; $\mathrm{kPa}$, kilopascals]

\begin{tabular}{|c|c|c|c|c|c|c|c|}
\hline $\begin{array}{c}\text { Trrie of } \\
\text { day }\end{array}$ & $\begin{array}{l}\text { Alr temperature } \\
\left({ }^{\circ} \mathrm{C}\right)\end{array}$ & $\begin{array}{l}\text { Relative } \\
\text { humidity } \\
\text { (percent) }\end{array}$ & $\begin{array}{c}\text { Solar } \\
\text { radiation } \\
\left(w / m^{2}\right)\end{array}$ & $\begin{array}{l}\text { Mean wind } \\
\text { speed } \\
\text { (m/s) }\end{array}$ & $\begin{array}{l}\text { Mean wind vector } \\
\text { magnitude } \\
(\mathrm{m} / \mathrm{s})\end{array}$ & $\begin{array}{l}\text { Wind vector } \\
\text { direction } \\
\text { (azimuthal deg) }\end{array}$ & $\begin{array}{c}\text { Barometric } \\
\text { pressure } \\
\text { (kPa) }\end{array}$ \\
\hline 0915 & 28.9 & 25 & 838 & 2.9 & 2.6 & 119 & 86.753 \\
\hline 0930 & 29.2 & 24 & 859 & 3.3 & 2.9 & 127 & 86.756 \\
\hline 0945 & 29.5 & 23 & 885 & 3.9 & 3.8 & 134 & 86.755 \\
\hline 1000 & 29.6 & 19 & 917 & 4.1 & 3.8 & 132 & 86.757 \\
\hline 1015 & 29.9 & 18 & 939 & 4.0 & 3.7 & 125 & 86.748 \\
\hline 1030 & 30.3 & 17 & 965 & 4.1 & 3.8 & 129 & 86.750 \\
\hline 1045 & 30.6 & 17 & 984 & 2.9 & 2.5 & 121 & 86.747 \\
\hline 1100 & 30.8 & 15 & 999 & 3.4 & 3.0 & 127 & 86.742 \\
\hline 1115 & 30.8 & 13 & 1013 & 4.2 & 3.9 & 124 & 86.735 \\
\hline 1130 & 31.2 & 12 & 1022 & 4.3 & 4.2 & 129 & 86.725 \\
\hline 1145 & 31.6 & 12 & 1026 & 3.5 & 3.2 & 123 & 86.709 \\
\hline 1200 & 31.9 & 12 & 1027 & 4.1 & 3.8 & 132 & 86.695 \\
\hline 1215 & 32.2 & 11 & 1028 & 3.7 & 3.3 & 127 & 86.686. \\
\hline 1230 & 32.5 & 11 & 1022 & 4.3 & 3.9 & 124 & 86.669 \\
\hline 1245 & 32.9 & 11 & 1016 & 3.1 & 2.6 & 122 & 86.661 \\
\hline 1300 & 33.1 & 11 & 1002 & 3.7 & 2.5 & 109 & 86.648 \\
\hline 1315 & 33.2 & 11 & 987 & 4.1 & 3.5 & 121 & 86.629 \\
\hline 1330 & 33.1 & 11 & 970 & 2.6 & 0.8 & 132 & 86.625 \\
\hline 13.45 & 33.0 & 11 & 947 & 4.1 & 3.1 & 100 & 86.614 \\
\hline 14100 & 33.1 & 10 & 916 & 2.6 & 1.4 & 139 & 86.599 \\
\hline 1415 & 33.5 & 10 & 885 & 3.7 & 2.7 & 103 & 86.5.69 \\
\hline 1430 & 33.5 & 10 & 851 & 2.8 & 1.8 & 107 & 86.557 \\
\hline 1445 & 34.0 & 10 & 817 & 3.5 & 2.9 & 114 & 86.539 \\
\hline 1500 & 33.6 & 10 & 780 & 3.2 & 2.3 & 104 & 86.529 \\
\hline 1515 & 33.6 & 10 & 736 & 4.3 & 3.1 & 89 & 86.513 \\
\hline 1530 & 33.3 & 10 & 697 & 3.0 & 2.2 & 122 & 86.500 \\
\hline 1545 & 33.9 & 10 & 654 & 3.5 & 1.8 & 87 & 86.4.94 \\
\hline 1600 & 33.9 & 10 & 606 & 2.9 & 1.7 & 100 & 86.4 .82 \\
\hline 16115 & 33.5 & 10 & 556 & 3.9 & 2.7 & 78 & 86.4 .69 \\
\hline $16: 30$ & 33.1 & 10 & 506 & 3.1 & 2.4 & 56 & 86.4.58 \\
\hline $16<5$ & 33.3 & 9 & 454 & 3.4 & 2.5 & 80 & 86.4.54 \\
\hline 1700 & 33.3 & 9 & 401 & 3.2 & 1.8 & 48 & 86.4.55 \\
\hline 1715 & 32.9 & 10 & 345 & 3.1 & 1.6 & 71 & 86.4 .53 \\
\hline 1730 & 32.5 & 10 & 96 & 2.7 & 1.9 & 11 & 86.4.50 \\
\hline 1745 & 31.1 & 10 & 24 & 2.2 & 1.7 & 14 & 86.4 .47 \\
\hline 1800 & 30.5 & 10 & 22 & 2.0 & 1.1 & 47 & 86.4 .41 \\
\hline
\end{tabular}


Table 3. Daily meteorological data from weather station WX-3 for June $21,1994-$ Continued

[Time of day in Pacific standard time; ${ }^{\circ} \mathrm{C}$, degrees Celsius; $\mathrm{w} / \mathrm{m}^{2}$, watts per square meter; $\mathrm{m} / \mathrm{s}$, meters per second; deg, degrees; $\mathrm{kPa}$, kilopascals]

\begin{tabular}{|c|c|c|c|c|c|c|c|}
\hline $\begin{array}{l}\text { Time of } \\
\text { day }\end{array}$ & $\begin{array}{l}\text { Air temperature } \\
\left.\text { ( }{ }^{\circ} \mathrm{C}\right)\end{array}$ & $\begin{array}{l}\text { Relative } \\
\text { humidity } \\
\text { (percent) }\end{array}$ & $\begin{array}{c}\text { Solar } \\
\text { radiation } \\
\left(w / m^{2}\right)\end{array}$ & $\begin{array}{l}\text { Mean wind } \\
\text { speed } \\
(\mathrm{m} / \mathrm{s})\end{array}$ & $\begin{array}{l}\text { Mean wind vector } \\
\text { magnitude } \\
(\mathrm{m} / \mathrm{s})\end{array}$ & $\begin{array}{l}\text { Wind vector } \\
\text { direction } \\
\text { (azimuthal deg) }\end{array}$ & $\begin{array}{l}\text { Barometric } \\
\text { pressure } \\
\text { (kPa) }\end{array}$ \\
\hline 1815 & 30.4 & 11 & 19 & 2.0 & 1.6 & 14 & 86.4 .45 \\
\hline 1830 & 30.0 & 11 & 16 & 1.5 & 0.8 & 61 & 86.4 .50 \\
\hline 1845 & 29.7 & 11 & 12 & 1.6 & 1.3 & 119 & 86.4 .45 \\
\hline 1900 & 29.1 & 11 & 8 & 1.1 & 0.5 & 158 & 86.4 .49 \\
\hline 1915 & 27.2 & 12 & 4 & 1.7 & 1.6 & 309 & 86.4 .56 \\
\hline 1930 & 25.5 & 12 & 1 & 2.4 & 2.4 & 310 & 86.4.65 \\
\hline 1945 & 25.0 & 13 & 0 & 2.3 & 2.2 & 320 & 86.4 .82 \\
\hline 2000 & 24.9 & 13 & 0 & 2.4 & 2.4 & 305 & 86.4 .93 \\
\hline 2015 & 24.9 & 13 & 0 & 2.0 & 1.9 & 307 & 86.505 \\
\hline 2030 & 25.0 & 13 & 0 & 2.0 & 2.0 & 304 & 86.527 \\
\hline 2045 & 24.7 & 13 & 0 & 2.2 & 2.2 & 304 & 86.544 \\
\hline 2100 & 24.5 & 13 & 0 & 2.2 & 2.2 & 309 & 86.553 \\
\hline 2115 & 24.0 & 13 & 0 & 2.4 & 2.3 & 311 & 86.560 \\
\hline 2130 & 23.6 & 14 & 0 & 2.4 & 2.4 & 309 & 86.566 \\
\hline 2145 & 23.2 & 14 & 0 & 2.4 & 2.3 & 311 & 86.574 \\
\hline 2200 & 23.0 & 14 & 0 & 2.6 & 2.5 & 311 & 86.580 \\
\hline 2215 & 23.0 & 14 & 0 & 2.4 & 2.4 & 310 & 86.583 \\
\hline 2230 & 22.6 & 15 & 0 & 2.4 & 2.4 & 312 & 86.589 \\
\hline 2245 & 22.6 & 15 & 0 & 2.4 & 2.4 & 305 & 86.589 \\
\hline 2300 & 22.4 & 15 & 0 & 2.4 & 2.4 & 304 & 86.590 \\
\hline 2315 & 22.3 & 15 & 0 & 2.2 & 2.2 & 309 & 86.587 \\
\hline 2330 & 22.3 & 15 & 0 & 2.1 & 2.1 & 309 & 86.590 \\
\hline 2345 & 22.0 & 15 & 0 & 2.2 & 2.1 & 302 & 86.590 \\
\hline 2400 & 22.2 & 15 & 0 & 2.3 & 2.3 & 296 & 86.592 \\
\hline
\end{tabular}


the sensitivity of the data logger was improperly set, and small changes in pressure were not recorded, which can be seen in the daily data files.

The rain gage was a 1-mm-resolution tipping bucket. The high-volume bucket makes the gage insensitive to small amounts of precipitation $(<1 \mathrm{~mm})$ but considerably reduces errors due to high-intensity storms. The data are available as yearly files designated as WX\#_PPT.OYR, where WX\# is the weather station number and YR is the last two digits of the calendar year.

A yearly weather-station file is also available. These files are designated was WX\#_DAY.OYR, where WX\# is the weather station number and YR is the last two digits of the calendar year. The data consist of day of year, solar radiation $\left(\mathrm{MJ} / \mathrm{m}^{2}\right)$, maximum temperature $\left({ }^{\circ} \mathrm{C}\right)$, mean temperature $\left({ }^{\circ} \mathrm{C}\right)$, minimum temperature $\left({ }^{\circ} \mathrm{C}\right)$, maximum relative humidity (percent), mean relative humidity (percent), minimum relative humidity (percent), maximum wind speed $(\mathrm{m} / \mathrm{s})$, mean wind speed $(\mathrm{m} / \mathrm{s})$, minimum wind $\operatorname{speed}(\mathrm{m} / \mathrm{s})$, and total daily precipitation $(\mathrm{mm})$. The data were based on the 15-minute averages. If data were missing for any part of the day, then -99 appears. In addition to the three types of data files, there is also a header file, WX\#_HDR.OYR, which provides information needed to identify the columns in each type of data file.

Two data summaries are presented. One summarizes the spatial distribution of selected properties; the other summarizes the yearly distribution at one location. The spatial variability of temperature in any one month is generally small (table 4), whereas the month-to-month variability is considerably higher (tables 4 and 6). The temporal variability of precipitation is high relative to the spatial variability (table 5). Precipitation in water year 1992 ranged from $160 \mathrm{~mm}$ to $279 \mathrm{~mm}$, due in large part to localized summer precipitation and elevation effects during winter precipitation (Hevesi and others, 1992a,b;

Hevesi, J.A., Ambos, D.S. and Flint, A.L., U.S. Geological Survey, written commun., 1996; Ambos and others, 1995). Annual precipitation at weather station WX-3 ranged from $12 \mathrm{~mm}$ in water year 1989, to $312 \mathrm{~mm}$ in water year 1993 (table 7).

The period of record for data in this report includes May 3, 1989, the date on which the USGS began working under an approved quality-assurance program. Data collected before that date were rigorously collected and are scientifically valid but should not be assumed to be supportable for purposes for which the approved quality-assurance program is mandatory.

Table 4. Maximum and minimum monthly air temperature for five weather stations for water year 1992

[Max, inaximum air temperature; Min, minimum air temperature]

\begin{tabular}{|c|c|c|c|c|c|c|c|c|c|c|c|c|c|}
\hline \multirow{2}{*}{$\begin{array}{l}\text { Weather } \\
\text { statlon }\end{array}$} & \multicolumn{13}{|c|}{$\begin{array}{c}\text { Alr temperature } \\
\text { (degrees Celsius) }\end{array}$} \\
\hline & & Oct & Nov & Deo: & Jan & Feb & Mar & Apr & May & Jun & Jul & Aug & Sep \\
\hline \multirow[t]{2}{*}{ WX-1 } & Max & 34.0 & 27.6 & 18.9 & 20.3 & 21.7 & 21.7 & 31.1 & 32.5 & 37.4 & 38.5 & 39.7 & 34.8 \\
\hline & Min & -1.6 & -2.3 & -3.2 & -2.8 & -0.8 & 3.8 & 5.9 & 9.4 & 7.9 & 13.2 & 14.6 & 13.5 \\
\hline \multirow[t]{2}{*}{ WX-2 } & Max & 34.7 & 27.6 & 18.4 & 20.5 & 22.9 & 23.1 & 32.4 & 33.5 & 38.3 & 39.9 & 41.1 & 35.9 \\
\hline & Min & -2.3 & -5.3 & -8.0 & -3.5 & -1.6 & 0.8 & 4.4 & 9.0 & 6.6 & 10.9 & 11.0 & 13.3 \\
\hline \multirow[t]{2}{*}{ WX-3 } & Max & 32.8 & 25.9 & 17.8 & 18.4 & 21.1 & 20.7 & 29.4 & 30.7 & 36.0 & 37.8 & 38.4 & 33.9 \\
\hline & Min & -2.7 & -4.1 & -4.7 & -3.2 & -1.9 & 2.0 & 2.7 & 8.4 & 7.2 & 11.6 & 13.7 & 12.7 \\
\hline \multirow[t]{2}{*}{ WX-4 } & $\operatorname{Max}$ & 31.3 & 25.2 & 16.0 & 16.9 & 19.5 & 19.4 & 29.3 & 31.1 & 37.4 & 38.0 & 38.4 & 33.5 \\
\hline & Min & -2.8 & -5.1 & -6.2 & -3.0 & -1.9 & 1.4 & 6.0 & 10.5 & 7.7 & 12.0 & 15.8 & 11.6 \\
\hline \multirow[t]{2}{*}{ WX-5 } & $\operatorname{Max}$ & 29.2 & 22.5 & 14.0 & 14.8 & 17.4 & 17.8 & 26.5 & 26.1 & 31.1 & 33.8 & 35.8 & 30.6 \\
\hline & Min & -4.3 & -7.7 & -7.9 & -6.5 & -4.6 & -0.1 & 3.8 & 7.8 & 8.8 & 9.7 & 13.9 & 13.0 \\
\hline
\end{tabular}


Table 5. Total monthly precipitation for five weather stations for water year 1992

$[--$, missing data $]$

\begin{tabular}{ccccccccccccc}
\hline $\begin{array}{l}\text { Weather } \\
\text { station }\end{array}$ & \multicolumn{10}{c}{} & \multicolumn{10}{c}{$\begin{array}{c}\text { Precipltation } \\
\text { (millimeters) }\end{array}$} \\
\cline { 2 - 12 } & & Oct & Nov & Dec & Jan & Feb & Mar & Apr & May & Jun & Jul & Aug \\
\hline WX-1 & 2 & 0 & 28 & 37 & 81 & 76 & 0 & 4 & 0 & 0 & 2 & 0 \\
WX-2 & 4 & 3 & 19 & 24 & 50 & 59 & 0 & 1 & 0 & 0 & 0 & 0 \\
WX-3 & 2 & 0 & 22 & 36 & 102 & 88 & 0 & 4 & 0 & 3 & 0 & 18 \\
WX-4 & 0 & 0 & 18 & 29 & 79 & 86 & 0 & 3 & 0 & 28 & 35 & 1 \\
WX-5 & -- & 0 & 21 & 38 & 109 & 81 & 1 & - & 0 & 25 & - & 0 \\
\hline
\end{tabular}

Table 6. Maximum and minimum monthly air temperature for weather station WX-3 for water years 1988-94

[Max, maximum air temperature; Min, minimum air temperature]

\begin{tabular}{|c|c|c|c|c|c|c|c|c|c|c|c|c|c|}
\hline \multirow{2}{*}{$\begin{array}{c}\text { Weather } \\
\text { station }\end{array}$} & \multicolumn{13}{|c|}{$\begin{array}{c}\text { Air temperature } \\
\text { (degrees Celsius) }\end{array}$} \\
\hline & & Oct & Nov & Dec & Jan & Feb & Mar & Apr & May & Jun & Jul & Aug & Sep \\
\hline \multirow[t]{2}{*}{1988} & $\operatorname{Max}$ & 34.2 & 20.2 & 14.7 & 16.7 & 21.1 & 26.1 & 27.1 & 31.8 & 37.1 & 41.4 & 36.9 & 37.4 \\
\hline & Min & 6.5 & -2.7 & -8.2 & -9.1 & -3.7 & -2.3 & 1.9 & 0.0 & 4.4 & 15.9 & 15.2 & 8.2 \\
\hline \multirow[t]{2}{*}{1989} & $\operatorname{Max}$ & 32.0 & 25.9 & 21.5 & 20.0 & 23.5 & 24.1 & 32.5 & 33.3 & 37.6 & 41.9 & 37.9 & 33.6 \\
\hline & Min & 12.0 & -2.2 & -14.2 & -8.2 & -14.3 & -5.5 & -0.8 & 2.2 & 14.5 & 16.7 & 14.5 & 7.2 \\
\hline \multirow[t]{2}{*}{1990} & Max & 30.8 & 25.7 & 22.8 & 20.9 & 22.6 & 26.4 & 29.5 & 30.8 & 39.0 & 10.2 & 39.5 & 35.3 \\
\hline & Min & -2.4 & -2.7 & -4.6 & -5.0 & -8.8 & -4.0 & 3.8 & 7.2 & 8.0 & 15.8 & 12.3 & 12.7 \\
\hline \multirow[t]{2}{*}{1991} & Max & 28.5 & 25.4 & 18.0 & 16.5 & 21.7 & 18.0 & 24.5 & 29.6 & 36.1 & 40.2 & 36.0 & 35.9 \\
\hline & Min & 4.5 & -6.1 & -15.1 & -6.2 & -1.8 & -3.3 & -1.5 & 0.1 & 8.8 & 16.4 & 12.9 & 9.4 \\
\hline \multirow[t]{2}{*}{1992} & Max & 32.8 & 25.9 & 17.8 & 18.4 & 21.1 & 20.7 & 29.4 & 30.7 & 36.0 & 37.8 & 38.4 & 33.9 \\
\hline & Min & -2.7 & -4.1 & -4.7 & -3.2 & -1.9 & 2.0 & 2.7 & 8.4 & 7.2 & 11.6 & 13.7 & 12.7 \\
\hline \multirow[t]{2}{*}{1993} & Max & 31.7 & 22.7 & 15.5 & 16.7 & 15.6 & 23.6 & 28.0 & 29.7 & 37.3 & 38.3 & 40.8 & 38.1 \\
\hline & Min & 5.8 & -4.6 & -7.1 & -9.6 & -3.4 & -2.7 & 1.8 & 7.3 & 3.7 & 13.7 & 13.1 & 8.7 \\
\hline \multirow[t]{2}{*}{1994} & Max & 33.6 & 23.2 & 16.6 & 22.5 & 17.7 & 25.5 & 19.8 & 33.0 & 40.3 & 38.5 & 38.5 & 33.9 \\
\hline & Min & 5.8 & -6.1 & -3.5 & -4.2 & -6.0 & -1.3 & -0.9 & 1.8 & 10.8 & 17.2 & 17.2 & 7.8 \\
\hline
\end{tabular}


Table 7. Total monthly precipitation values for weather station WX-3 for water years 1988-94

\begin{tabular}{lcccccccccccc}
\hline $\begin{array}{l}\text { Weather } \\
\text { station }\end{array}$ & \multicolumn{10}{c}{} & \multicolumn{10}{c}{$\begin{array}{c}\text { Precipitation } \\
\text { (millimeters) }\end{array}$} \\
\cline { 2 - 12 } & & Oct & Nov & Dec & Jan & Feb & Mar & Apr & May & Jun & Jul & Aug \\
\hline 1988 & 25 & 40 & 22 & 5 & 14 & 1 & 50 & 13 & 0 & 3 & 9 & 12 \\
1989 & 0 & 1 & 2 & 1 & 8 & 0 & 0 & 0 & 0 & 0 & 0 & 0 \\
19910 & 0 & 0 & 0 & 12 & 3 & 2 & 8 & 12 & 0 & 4 & 13 & 9 \\
1991 & 0 & 3 & 0 & 3 & 24 & 61 & 0 & 14 & 2 & 0 & 18 & 7 \\
1992 & 2 & 0 & 22 & 36 & 102 & 88 & 0 & 4 & 0 & 3 & 0 & 18 \\
1993 & 17 & 0 & 76 & 79 & 83 & 25 & 1 & 0 & 22 & 0 & 7 & 2 \\
1994 & 10 & 11 & 10 & 14 & 27 & 21 & 19 & 11 & 0 & 1 & 0 & 4 \\
\hline
\end{tabular}

\section{SUMIMARY}

Meteorological data were collected from five weather stations on and around Yucca Mountain, Nevada, from April 1987 through September 1994. The measurements include solar radiation, temperature, relative humidity, wind speed, wind vector magnitude, wind direction, wind vector direction, barometric pressure, and precipitation. The range of air temperature and precipitation was presented to indicate the differences between water years at a single location and between weather station locations for a single year.

Precipitation at one site (WX-3) ranged from a low of $12 \mathrm{~mm}$ in water year 1989 to a high of $312 \mathrm{~mm}$ in water year 1993. At the same location, air temperature ranged from a low of $-15.1^{\circ} \mathrm{C}$ in December 1990 (water year 1991) to a high of $41.9^{\circ} \mathrm{C}$ in July 1989 (water year 1989). The weather station network also provides information on spatial variability of meteorological conditions over the site.

\section{REFERENCES CITED}

Ambos, D.S., Hevesi, J.A., and Flint, A.L., 1995, Precipitation data for water years 1992 and 1993 from a network of nonrecording gages at Yucca Mountain, Nevada: U.S. Geological Survey Open-File Report 95$146,100 \mathrm{p}$.

Flint, A.L., and Childs, S.W., 1991, Modification of the Priestley-Taylor equation to estimate evapotranspiration for soil water limited conditions: Journal of Agricultural and Forest Meteorology, v. 56, p. 247-260.

Hevesi, J.A., Istok, J.D., and Flint, A.L., 1992a, Precipitation estimation in mountainous terrain using multivariate geostatistics - I. Structural analysis: Journal of Applied Meteorology, v. 31, p. 661-676. 1992b, Precipitation estimation in mountainous terrain using multivariate geostatistics-II. Isohyetal maps: Journal of Applied Meteorology, v. 31, p. 661-676.

Monteith, J.L., and Unsworth, M.H., 1990, Principles of environmental physics: New York, American Elsevier, $291 \mathrm{p}$.

U.S. Department of Energy, 1988, Yucca Mountain site characterization plan: U.S. Department of Energy, DOE/RW-0199. 